\title{
Shallow-water late middle Eocene crinoids from Tierra del Fuego: a new southern record of a retrograde community structure*
}

\author{
NORBERTO MALUMIÁN ${ }^{1}$ and EDUARDO B. OLIVERO ${ }^{2}$ \\ ${ }^{1}$ SEGEMAR-CONICET, Benjamín Lavaissé 1194; (C1107BJD) Buenos Aires, Argentina. \\ E-mail: malumian@mpgeo1.gov.ar \\ ${ }^{2}$ CADIC-CONICET, Ushuaia, Argentina.
}

\begin{abstract}
SUMMARY: One of the very few crinoid records in Patagonia is that of the abundant columnals of the genus Isselicrinus found in several localities in shallow marine, glauconitic sandstones of the Leticia Formation (upper middle Eocene of Tierra del Fuego Island). Some of them, up to $10 \mathrm{~cm}$ long, are preserved in a position almost perpendicular to the stratification, which is attributed to episodes of high sedimentation rate. The Isselicrinus remains occur either almost alone or associated with solitary corals, gastropods, bivalves, rare nautilids, shark teeth, penguin bones and well-preserved specimens of Ophiura elegantoides. The associated microfossils, mainly Foraminifera, are characterised by the anomalous abundance and dominance of large Nodosariacea. These records reflect a peculiar success of a retrograde, dense, suspension-feeding crinoid population as a regional extension of previously described distribution in the Antarctic upper Eocene.
\end{abstract}

Keywords: Tierra del Fuego, Eocene, Leticia Formation, shallow-marine, crinoids, Isselicrinus, Nodosariacea, retrograde community structure.

RESUMEN: CRINOIDEOS DE AMBIENTES SOMEROS EN EL EOCENO MEDIO TARDío DE TIERRA DEL FuEgO: NuEVO REGISTRO AUSTRAL DE UNA COMUNIDAD CON ESTRUCTURA RETRÓGRADA. - Uno de los pocos registros de crinoideos en Patagonia está representado por abundantes columnas del género Isselicrinus, en areniscas glauconíticas someras de la Formación Leticia (Eoceno Medio superior de Tierra del Fuego). Algunas columnas, de hasta $10 \mathrm{~cm}$ de largo, están preservadas en forma casi perpendicular a la estratificación, posición que se atribuye a episodios de alta tasa de sedimentación. Los restos de Isselicrinus se presentan en forma aislada o están asociados a corales solitarios, gastrópodos, bivalvos, escasos nautiloideos, dientes de tiburones, huesos de pingüinos, y ejemplares bien preservados de Ophiura elegantoides. Los microfósiles asociados, principalmente foraminíferos, se caracterizan por la dominancia y abundancia anómala de grandes conchillas de Nodosariacea. Estos registros reflejan un peculiar éxito de poblaciones suspensívoras, retrógradas y densas, de crinoideos y demuestran una extensión regional de poblaciones similares descriptas para el Eoceno superior de Antártida.

Palabras clave: Tierra del Fuego, Eoceno, Formación Leticia, ambientes someros, crinoideos, Isselicrinus, Nodosariacea, comunidades de estructura retrógrada.

\section{INTRODUCTION}

The Mesozoic marine biotic revolution is thought to have caused irreversible changes in the life habits of many invertebrates. This is exempli-

*Received May 10, 2004. Accepted March 24, 2005. fied by the stalked isocrinid crinoids, which today are only known in deep-water environments. When they appeared in the Triassic, isocrinids were mostly restricted to shallow waters but, with few exceptions, during the Late Cretaceous they migrated to deep-water settings (Bottjer and Jablonski, 1988). Crinoids from Tierra del Fuego have been known 


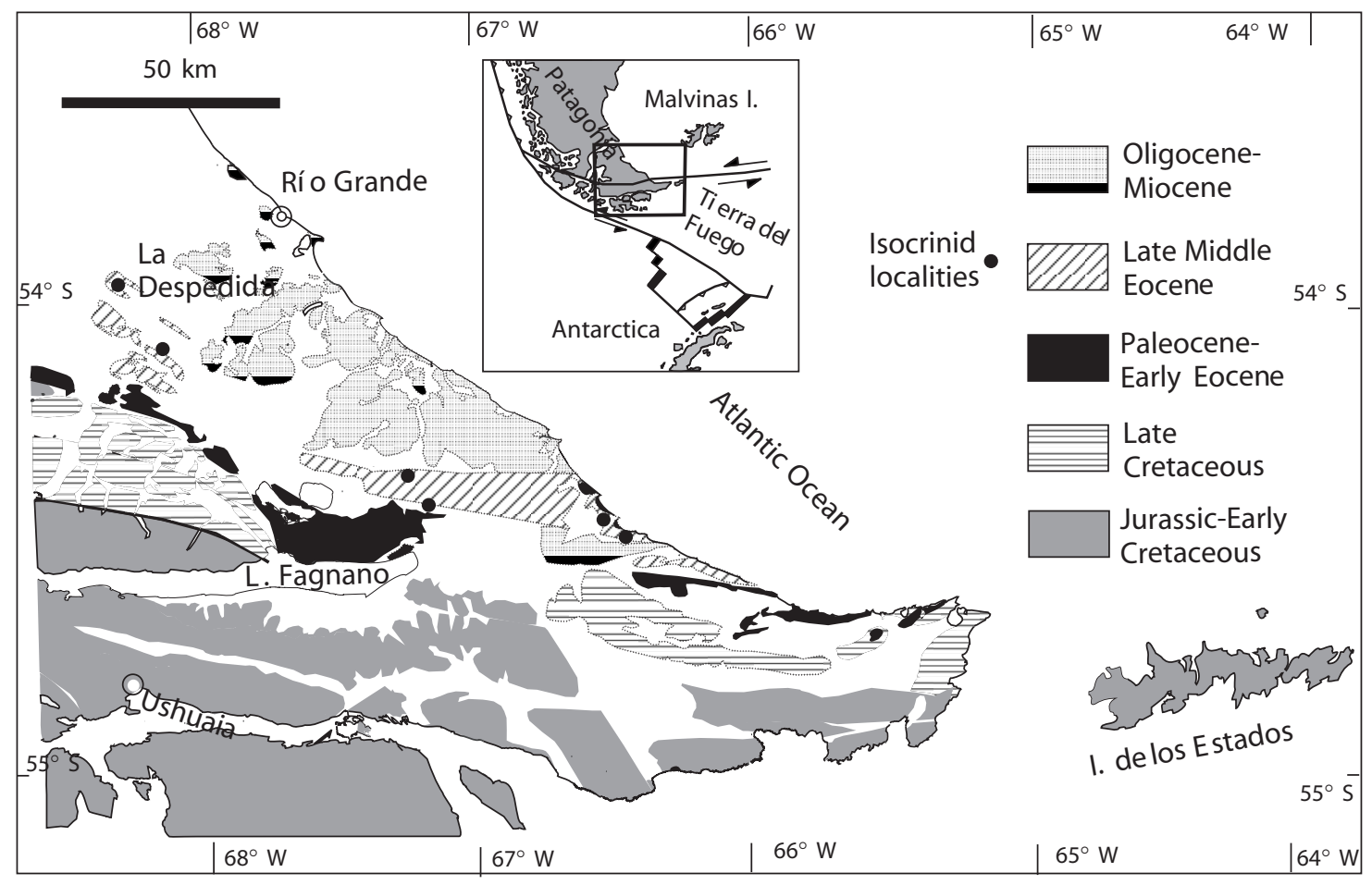

FIG. 1. - Schematic geology of Tierra del Fuego, distribution of upper middle Eocene rocks, and localities with the fossil isocrinid Isselicrinus $\mathrm{sp}$.

since the beginning (Doello-Jurado, 1922) and middle of the last century (Furque and Camacho, 1949) in the La Despedida and Leticia beds, originally dated as Cretaceous-Early Cenozoic and Late Cretaceous respectively. However, Codignotto and Malumián (1981) and Olivero and Malumián (1999, and unpublished results) indicate that fossil crinoids from the Argentinean portion of the Tierra del Fuego Island are all isocrinids restricted to the shallowwater Leticia Formation of late middle Eocene age (Fig. 1). The palaeoecologic and stratigraphic impli-

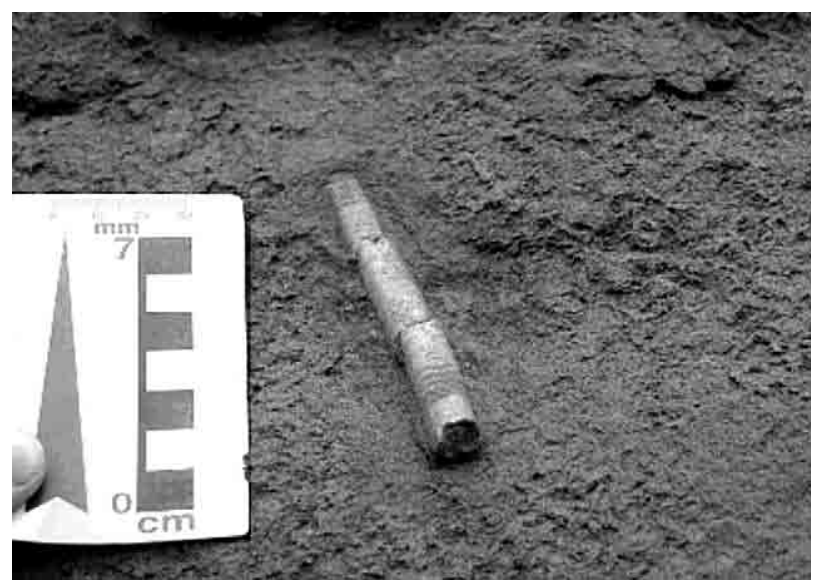

FIG. 2. - Vertical column of Isselicrinus sp. preserved almost perpendicular to the stratification in glauconitic sandstones of the Leticia Formation, late middle Eocene, Tierra del Fuego. cations of these anomalous, shallow-marine isocrinids are addressed and compared with similar records, mainly from Antarctica.

\section{DISTRIBUTION AND RECORD OF ISOCRINID CRINOIDS IN TIERRA DEL FUEGO}

Short segments of the column of stalked crinoids, sometimes preserved almost perpendicular to the stratification (Fig. 2), are common to abundant in certain fine, glauconitic, sandstone beds of the Leticia Formation in different localities of the central and coastal parts of Tierra del Fuego Island (Fig. 1). Segments of the column, occasionally up to $10 \mathrm{~cm}$ long, are the only preserved parts; isolated cups or partial broken arms were not recorded. The section of the column is pentagonal or less frequently cylindrical and the nodals bear three small, subcircular cirrus sockets (Fig. 3). Based on these features the material is assigned to Isselicrinus sp.

In the coastal localities, Isselicrinus sp. is associated with an abundant megafauna, which comprises solitary corals, gastropods, bivalves, rare nautilids, shark teeth (Olivero and Malumián, 1999), penguin bones (Clarke et al., 2003), and in particular wellpreserved specimens of Ophiura elegantoides 


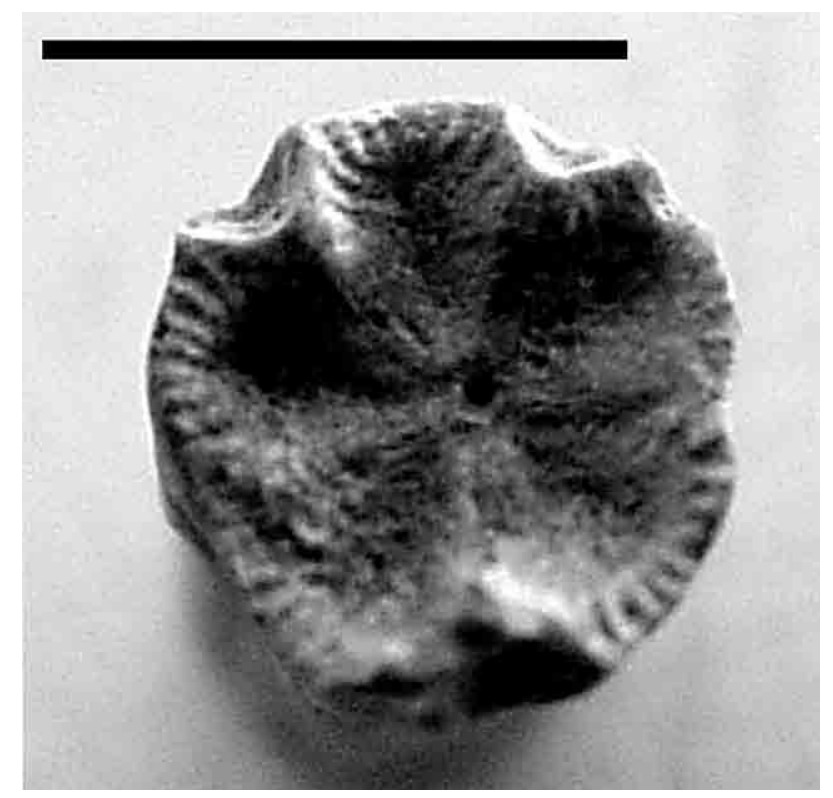

FIG. 3. - Vertical view of a nodal of Isselicrinus sp. with three cirrus sockets. Late middle Eocene, La Despedida Section, Tierra del Fuego. Scale bar $1 \mathrm{~cm}$.

(Furque and Camacho, 1949). In the central localities, the megafauna is poorly represented, but the associated Foraminifera are characterised by the great abundance of large Nodosariacea, which commonly reach up to $4 \mathrm{~mm}$ in length and are the largest calcareous Foraminifera found in Argentina (Malumián, 1990). The sedimentology, ichnology, and foraminiferal assemblages all indicate shallow marine to marginal marine settings, including estuarine and subtidal channel environments, for the crinoid-bearing Leticia Formation (Olivero and Malumián, 1999). The record of the first appearance datum of the planktonic foraminiferan Globigeri- natheka index (Finlay), just below the crinoid horizons, indicates a late middle Eocene age for the Leticia Formation (not older than $42.9 \mathrm{Ma}$, $c f$. Berggren et al., 1995).

Recent studies in Tierra del Fuego recognised a rather complete Upper Cretaceous-Middle Miocene stratigraphic column. The Upper Cretaceous, part of the Palaeocene, and the Lower Eocene are relatively deep-marine deposits; the Oligocene-Lower Miocene are deep-marine deposits; and parts of the Palaeocene and Eocene, and the Middle Miocene are shallow-marine deposits (Olivero et al., 2002, 2003). Isocrinid crinoids and ophiuroids are only known from the Leticia Formation and are apparently absent from the rest of the stratigraphic column in Tierra del Fuego. With the only exception of some scarce columnals records from the Danian (Fig. 4) that do not belong to the genus Isselicrinus, crinoids are also apparently absent in the rest of the shallow marine Patagonian Cenozoic deposits. In the Chilean portion of the Austral Basin, there is only a mention of Balanocrinus, in the Chorrillo Chico Formation (Charrier and Lahsen, 1969), recently assigned to a post-Danian Palaeocene age (Quattrocchio and Sarjeant, 2003).

\section{DISCUSSION}

Post-late Cretaceous, shallow-water records of fossil isocrinids are exceedingly rare and they are only known in the Southern Hemisphere. A few specimens of isocrinids were recorded in shallowwater deposits from New Zealand (Metacrinus sp. in
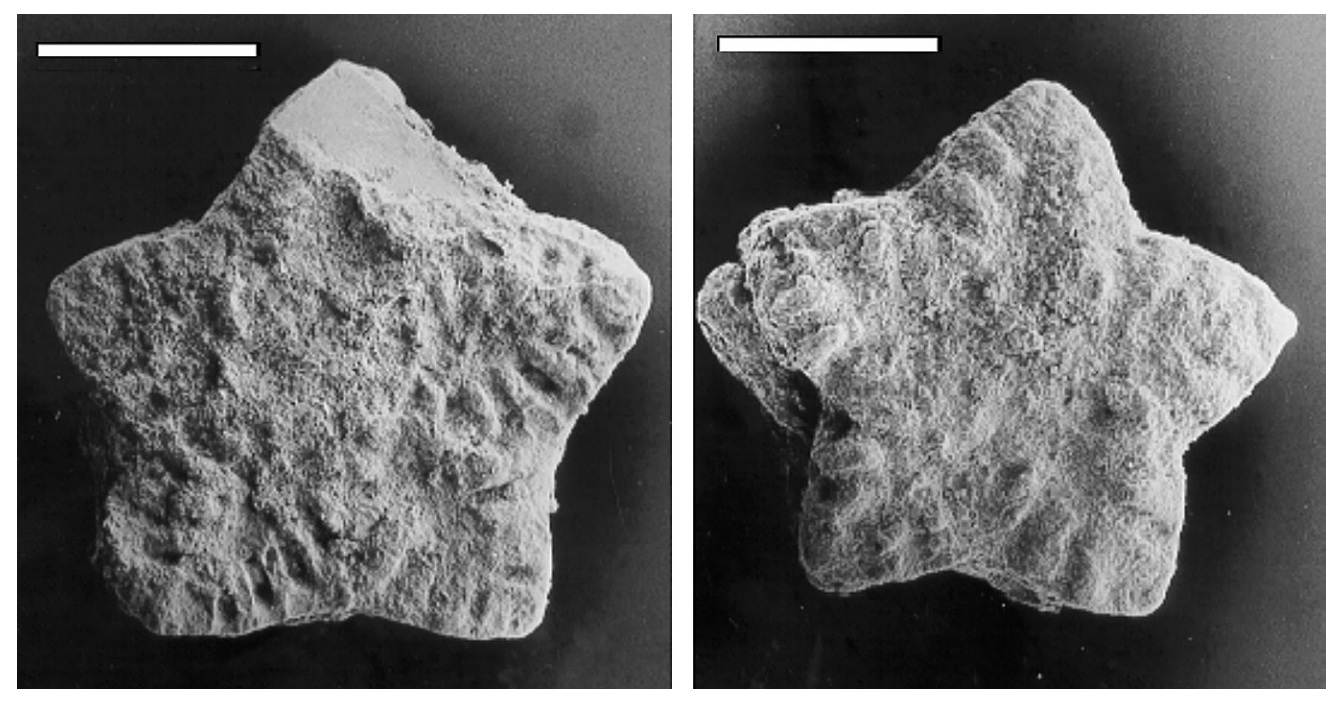

FIG. 4. - SEM photographs of isolated columnals of crinoids from the Salamanca Formation, Danian, Patagonia. Scale bar $1 \mathrm{~mm}$. 
Palaeocene conglomerates and indeterminate isocrinids in Oligocene limestones; Stilwell et. al., 1994) and Australia (Nielsenicrinus sp. in late Paleocene limestones; Oji, 1996). On the other hand, abundant specimens of Metacrinus fossilis Rasmussen, Eometacrinus australis Baumiller and Gazdzicki, and ophiuroids are known from the late Eocene subtidal deposits of the La Meseta Formation in Seymour Island, Antarctica (Rasmussen, 1979; Meyer and Oji, 1993; Baumiller and Gazdzicki, 1996). The abundance of $M$. fossilis in the late Eocene shallow-water, tidally influenced deposits of Antarctica is particularly significant as the only reliable known fossil species of a modern isocrinid genus widespread in deep-water settings in the IndoPacific region. Species of the genus Isselicrinus are also mostly restricted to deep-water settings in the Cenozoic. In parallel with M. fossilis from Antarcti$\mathrm{ca}$, the record of Isselicrinus sp. in the late middle Eocene of Tierra del Fuego demonstrated the shallow water occurrence of taxa that were prevalent in deep-water settings during the Cenozoic.

Only the cups and the proximal columnals are preserved in M. fossilis from Seymour Island, and this was interpreted as a secondary stalkless condition following autotomy of juvenile stalks during ontogeny (Meyer and Oji, 1993). On the other hand, only part of the stalk is preserved in Isselicrinus sp. from Tierra del Fuego. Isocrinids never have a radix and they are attached to the bottom by distal cirri. However, they sometimes lose the basal hold and drift away until the cirri grasp a new surface again; during this process, part of the distal column may break off and it could remain buried if followed by a sudden, highrate sedimentation event. Moreover, given the recent finding that stalk fragments detached and isolated from a living crinoid in aquaria can survive more than one year (Oji and Amemiya, 1998), the burial chances of parts of the remaining column could be very high. This is probably the best taphonomic explanation for the isolated, almost perpendicular-tobedding preservation of part of the column of Isselicrinus sp. in the Leticia Formation.

Shallow-water, suspension feeder benthic communities with abundant stalked crinoids were dominant in the Paleozoic and their success was correlated with the lack of an intensive predation pressure. The success of bivalves and gastropods with defensive structures as the dominant benthic, shallowwater communities in the Cenozoic was related to the Mesozoic marine revolution, characterised by the increasing dominance of durophagous predators since the Jurassic, including sharks, teleostean fishes and crustacean decapods. The abundant record of isocrinids and ophiuroids in localised horizons in the late Eocene from Antarctica was considered as an anomaly and explained as a retrograde community reminiscent of Paleozoic marine and modern deepsea communities (Aronson et al., 1997, Aronson and Blake, 2001). Low-predation levels for the late Eocene as in the Paleozoic were interpreted as driven by global cooling and changes in productivity associated with increased upwelling in Antarctica (Aronson and Blake, 1997).

The finding that the isocrinid crinoids from Tierra del Fuego are stratigraphically restricted to the late middle Eocene has significant palaeoecologic implications, as it clearly indicates a regional extension of anomalous, suspension-feeding communities with abundant stalked crinoids in the late middle and late Eocene of the southern ocean. The anomalous success of retrograde, dense, suspension-feeding echinoid populations in the late Eocene of Antarctica has been explained by the joint combination of three critical conditions: low predation pressure; low rates of sediment resuspension; and a high flux of particulate organic mater. The accelerated cooling trend during the late Eocene was linked to the disappearance or marked diminution of durophagous predators and to the high productivity of particulate organic matter promoted by increased upwelling (Aronson and Blake, 1997, 2001).

Similar outstanding associated characteristics are inferred for the late middle Eocene of Tierra del Fuego. Abundant crinoid columns are recorded in glauconite-rich intervals, suggesting localised periods of low sedimentation rates. Recent observations demonstrate that the phosphatic concretions, so common in different late Eocene-Miocene conglomerates in Tierra del Fuego ( $c f$. Leanza and Hugo, 1992), have been reworked from late middle Eocene sediments, suggesting the existence of nutrient-rich oceanic waters during this time. The excellent preservation of the Foraminifera associated with isocrinids at La Despedida section is linked to disaerobic bottom conditions suggestive of a high flux of particulate organic matter. In addition, a striking feature is the absolute dominance and diversity of Nodosariacea in certain horizons. Absolute dominance of this superfamily is typical of the Jurassic and early Cretaceous, with a declining relative dominance in the Palaeocene, and thus the dominance of Nodosariacea in the late middle Eocene can also be considered as a retrograde feature. 
Extant isocrinids are stenothermal, living generally within a short range of temperatures and in the deep sea, where their bathymetric distribution is controlled by temperature (Oji, 1996). Fossil isocrinids were probably also stenothermal. Thus, it seems reasonable to assume that the late middle to late Eocene declining temperature of the seawater led to a decline in predation pressure and favoured the preferred range of temperature for different isocrinid groups at slightly different times, allowing the bloom of shallow-water, isocrinid populations in the Southern Ocean.

\section{ACKNOWLEDGEMENTS}

This study was partly financed by ANPCYTFONCYT PICT 07-8675. We thank T. Oji, University of Tokyo, for helping with the systematics of isocrinids and making valuable comments.

\section{REFERENCES}

Aronson, R.B. and D.B. Blake. - 1997. Global climate change and the paleoecology of echinoderm populations at Seymour Island, Antarctica. Antarct. J. US. Review, 32(5): 20-22.

Aronson, R.B. and D.B. Blake. - 2001. Global Climate Change and the origin of modern benthic communities in Antarctica. Am. Zool., 41: 27-39.

Aronson, R.B., D.B. Blake and T. Oji. - 1997. Retrograde community structure in the late Eocene of Antarctica. Geology, 25: 903-906.

Baumiller, T.K. and A. Gazdzicki. - 1996. New crinoids from the Eocene La Meseta Formation of Seymour Island, Antarctic Peninsula. Palaeontologica Polonica, 55: 101-116.

Berggren, W.A., D.V. Kent, C.C. Swisher III and M.P Aubry. 1995. A revised Cenozoic geochronology and chronostratigraphy. SEMP Society for Sedimentary Geology. Special Publication, 57: 120-212.

Bottjer D.J. and D. Jablonski. - 1988. Paleoenvironmental patterns in the evolution of post-Paleozoic benthic marine invertebrates. Palaios, 3: 540-560.
Charrier, R. and A. Lahsen. - 1969. Stratigraphy of Late Cretaceous-Early Eocene, Seno Skyring-Strait of Magellan area, Magallanes Province, Chile. Am. Assoc.Petr. Geol. B., 53(3): 568-533.

Clarke, J., E.B. Olivero and P. Puerta. - 2003. Report of the earliest fossil penguin from South America and first fossil vertebrate from the Paleogene of Tierra del Fuego, Argentina. American Museum Novitates, Number 3423: 1-18. December 2003.

Codignotto, J.O. and N. Malumián. - 1981. Geología de la región al norte del paralelo $54^{\circ} \mathrm{S}$ de la Isla Grande de la Tierra del Fuego. Rev. Asoc. Geol. Argentina, 36(1): 44-88.

Doello-Jurado, M. - 1922. Note préliminaire sur les résultats géologiques de l'expédition de l'université de Buenos Aires à la Terre de Feu (1921). Comptes Rendu XIIIe Sess. Congrès Géologique International, Belgique: 1519-20.

Furque, G. and H.H. Camacho. - 1949. El Cretácico Superior de la costa atlántica de Tierra del Fuego. Rev. Asoc. Geol. Argentina, 4: 263-297.

Leanza, H.A. and C.A. Hugo. - 1992. Los episodios fosfogénicos del Paleógeno de Argentina. Meeting in Punta Arenas, Abstracts: 21, IGCP proyectos 301/308.

Malumián, N. - 1990. Foraminíferos bentónicos de la localidad tipo de la Formación La Despedida (Eoceno, Isla Grande de Tierra del Fuego). Parte II, Nodosariacea, Buliminacea, Elphidiidae y rotálidos tuberculados. Ameghiniana, 27(3-4): 343-363.

Meyer, D.L. and Oji, T. - 1993. Eocene crinoids from Seymour Island, Antarctic Peninsula: Paleobiogeographic and paleoecologic implications. J. Paleontol., 67: 250-257.

Oji, T. - 1996. Is predation intensity reduced with increasing depth? Evidence from the west Atlantic stalked crinoid Endoxocrinus parrae (Gervais) and implications for the Mesozoic marine revolution. Paleobiology, 22(3): 339-351.

Oji, T. and S. Amemiya - 1998. Survival of crinoid stalk fragments and its taphonomic implications. Paleontol. Res., 2 (1): 67-70.

Olivero, E.B. and N. Malumián. - 1999. Eocene stratigraphy of southeastern Tierra del Fuego Island, Argentina. Am. Assoc.Petr. Geol. B., 83(2): 295-313.

Olivero, E.B., N. Malumián, S. Palamarczuck and R. Scasso. 2002. El Cretácico superior-Paleogeno del área del Río Bueno, costa atlántica de la Isla Grande de Tierra del Fuego. Rev. Asoc. Geol. Argentina, 37(3): 199-218.

Olivero, E.B., N. Malumián and S. Palamarczuk. - 2003. Estratigrafía del Cretácico Superior-Paleoceno del área de Bahía Tethis, Andes fueguinos, Argentina: acontecimientos tectónicos y paleobiológicos. Rev. Geol. Chile, 30(2): 245-263.

Quattrocchio, M. and A.S. Sarjeant. - 2003. Dinoflagellates from the Chorrillo Chico Formation (Paleocene) of southern Chile. Ameghiniana, 40 (2): 129-153.

Rasmussen, H.W. - 1979. Crinoideos del Cretácico Superior y del Terciario Inferior de la Isla Vicecomodoro Marambio (Seymour Island, Antártida). Contrib. Cient. Inst. Antárt. Argent., 4: 79-97.

Stilwell, J.D., R.E. Fordyce and P.J. Rolfe. - 1994. Paleocene isocrinids (Echinodermata: Crinoidea) from the Kauru Formation, South Island, New Zealand. J. Paleontol., 68(1): 135-141. 
